\title{
成形接合のメカニズム解明のための陽極酸化ポーラスの相似性を維持した サイズコントロール
}

\section{Controlling Size and Similarity of Anodic Porous to Reveal Joining Mechanism of Injection Molded Direct Joining}

\author{
木 村文信*・常昊*・陳＼cjkstart偉彦*・梶原優介* \\ Fuminobu KIMURA, Hao CHANG, Weiyan CHEN and Yusuke KAJIHARA
}

(Received 14 June 2021, Accepted 16 July 2021)

\begin{abstract}
This study presents an anodizing process controlling a pore size and surface porosity for injection molded direct joining (IMDJ). IMDJ is a technique of direct joining between an injection-molded plastic component and a surface-treated metal plate. A surface treated metal plate has a micro-/nano-structure on its surface, which can provide micro-/nano-interlocking with an injection-molded plastic component. Controlling geometry of a micro-/nano-structure is important to understand how the joining is formed. This study adopted an anodizing process as a surface treatment because it can produce nano-structures, the geometry of which is precisely controlled. To fabricate nano-structures being suitable for IMDJ, a wide variety of conditions for an anodizing process were investigated. Resultantly, we fabricated the nano porous structures that have different sizes but similar porosity: pore diameters of tens $\mathrm{nm}, 200 \mathrm{~nm}$, and $400 \mathrm{~nm}$ approximately. Using the three kinds of metal plates, we investigated the effect of molding condition on joining strength. The results showed that the injection speed, which is one of the molding parameters, had a negative correlation with the strength in any cases of nano-structures. The injection speed effects were also confirmed by an atomic force microscopy of the plastics infiltrating the nano-structures. Under the smaller structures (tens $\mathrm{nm}$ and $200 \mathrm{~nm}$ ), we could see same tendency. However, the tendency changed under the $400 \mathrm{~nm}$ porous structure condition. The results in the current state cannot give the perfect interpretation of the mechanism of joining occurrence; however it leads the further understanding in future.
\end{abstract}

Key Words: Metal-polymer Direct Joining, Anodizing, Nano-pores, Injection Molding

\section{1. 緒 言}

環境・エネルギー問題の観点から、自動車や航空機の軽 量化が社会的な課題になっている。軽量化のアプローチの 一つに、従来金属で構成していた構造を樹脂に置き換える といった方策が採られるようになっている。ただし、樹脂 のみでは十分な剛性や強度、耐久性が担保できない場合、 金属材料と併用した構造が必要となる。樹脂と金属を併用 するにあたり、従来はねじやリベットなどによる機械的締 結や接着剂を用いた方法で両材料を接合するのが一般的で あった。しかし近年は、より軽量な構造をより簡易に構築 するため、そういった接合のための部品・材料を用いない、 樹脂と金属を直接接合する技術の研究開発が盛んに進めら れるようになっている。

研究されている樹脂と金属の直接接合法は、樹脂部材 が成形されるタイミングの観点から、大きく分けて 2 種類 に分類できる。1つめは、あらかじめ成形された樹脂部材 と金属部材を接合する手法で、両材を重ね合わせた状態で 局所的に加熱する手法が多く採られている。局所加熱手

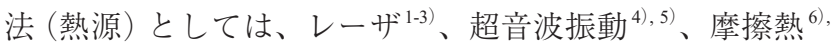

7)、ジュール熱 ${ }^{8)}$ などが用いられている。金属同士や樹脂同 士の溶接・溶着技術と同様のコンセプトである。2つめの 接合法は、樹脂部材の成形と直接接合が同時に達成される もので、樹脂成形には多くの場合に射出成形が用いられて いる。表面に微細な構造 (nm オーダから $\mu \mathrm{m}$ オーダ) が形 成された金属部材を金型の内部に設置し、その状態で樹脂 を射出成形することで、樹脂が冷却・固化して型から取り 出されるときに接合が完成しているというプロセスである

(Fig. 1)。金属表面の微細構造と射出成形を利用するこの方

(a) (b)

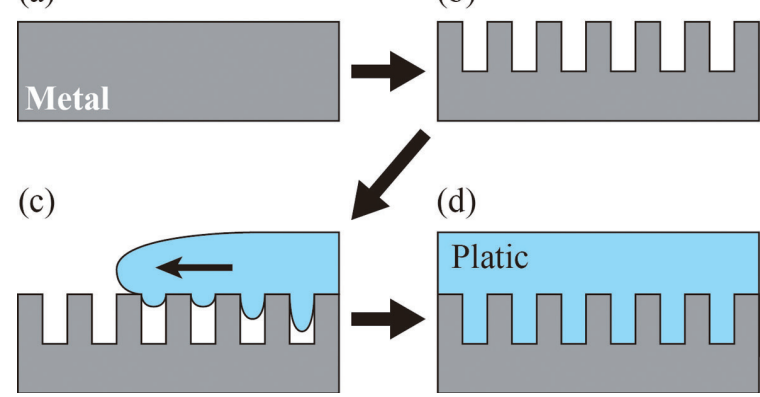

Fig. 1 Overview of IMDJ (injection molded direct joining).

*東京大学生産技術研究所（＝153-8505 東京都目黒区駒場 4-6-1）

Institute of Industrial Science, The University of Tokyo (4-6-1, Komaba, Meguro-ku, Tokyo 153-8505, Japan) 
法は、工程削減性や形状自由度の高さから最も期待できる 接合技術の 1 つと考えられており ${ }^{9}$ 、我々はこの技術を成形 接合 (Injection molded direct joining, IMDJ) と呼んで研究を進 めている。微細構造を形成する手法としては、ブラスト処 理 $^{10-12)}$ 、薬品処理 ${ }^{13-16)}$ 、陽極酸化処理 ${ }^{17), 18)}$ 、レーザ加工 ${ }^{19-21)}$ などが提案されている。成形接合は非常に期待されている が、幅広い実用化のためには、厳密な接合メカニズムの解明、 プロセス (加工条件) の最適化といった課題が残されている。

我々は成形接合に関する課題の取り組みとして、様々な 表面処理技術を横断して射出成形条件と接合強度の関係を 調査してきた。その中で、微細構造の種類 (形成方法) が異 なると、射出成形パラメータが接合強度に与える影響が大 きく変化するということが分かってきた。ある構造に対し ては射出速度と強度の間に正の相関があるのに対し、別の 構造に対しては負の相関を持つ ${ }^{16)}$ という特徵的な変化を確 認できた。ここで、それぞれの微細構造の特徵の中で最も 大きな違いは「サイズ」であると想定した(一方は $10 \mathrm{~nm}$ オー ダでもう一方は $10 \mu \mathrm{m}$ オーダであった $)$ 。射出速度 ( $\approx$ 溶融 樹脂の流速) が微細構造への侵入 (Fig. 1 (c)) に与える影 響が、微細構造のサイズに依存するのだと推定した。ただ し、接合が発現するメカニズムの解明を進めるためには、 サイズ依存性を精査する必要がある。

微細構造のサイズ依存性を検証するためには、サイズ以 外の特徵を揃え、サイズのみが変化した（相似形になる） 微細構造を用意する必要がある。サイズの制御性が高い表 面処理手法として陽極酸化処理に着目した。アルミニウム を陽極酸化処理することで、表面に円筒状の微細孔を含ん だ酸化膜が形成され、陽極酸化処理条件を変えることで孔 径やピッチなどが変化することが知られている ${ }^{22-25)}$ 。これ までの研究では、陽極酸化処理を施したアルミニウム片と 射出成形樹脂が接合できることを確認し ${ }^{17)}$ 、サイズ (孔径) が変わることで樹脂の微細孔への侵入挙動が変化すること を部分的に確認した ${ }^{18)}$ 。しかし、ピッチやポロシティ（み かけの表面積における微細孔の割合) などの孔径以外の要 素の制御や処理のバラツキを抑えることができておらず、 射出成形樹脂と接合できる条件が非常に限られているとい う問題があった。特に孔径が大きくなるほど接合が困難に なっており、これはポロシティが低いことが原因の 1 つだ と考えてきた。

そこで本研究では、成形接合の接合発現メカニズムや射 出成形中の樹脂流動をより深く理解するため、サイズは 異なるがポロシティが同程度になる、つまり相似性の高い 多様な微細孔配列を陽極酸化処理によって形成することを 検討する。陽極酸化処理による微細孔制御に関する先行 研究のほとんどが、非常に純度の高いアルミニウム（純度 99.99\% 以上）を用いていたのに対し、本研究では入手性の 高いA1050やA5052（合金）といったグレードを用いて、 微細孔のサイズ制御を行う。入手性の高い一般工業材料に おいても微細孔を高精度に制御できるようになれば、将来
的に成形接合を幅広く産業応用に発展させる際に有用な知 見になると考えられる。

\section{2. 陽極酸化処理}

アルミニウムに対して陽極酸化処理を施すと、円筒形状 の微細孔が規則的に並んだ酸化膜が形成される。その構造 は Keller モデル ${ }^{22)}$ として知られており、Fig. 2 に示すよう に、セルと呼ばれる六角柱の中心に微細孔が配置され、セ ルの集合によるハニカム構造の膜になる。微細孔の底部と アルミニウム素地の間の層はバリヤー層と呼ばれる。微細 孔間の距離（試験片表面方向における各セルのサイズ・径と 等価）はセル径、微細孔の直径は孔径と呼ばれる。陽極酸化 条件が酸化膜構造に与える影響は未だ不明な点も多い ${ }^{24)}$ が、 おおまかには、電圧によってセル径（微細孔間の距離）と孔 径が変化し、処理時間によって膜の厚さが变化する（酸化 膜が成長する時間が変わるため)。陽極酸化処理のみでは、 セル径と孔径を独立して制御することができないため、ポ ロシティを調整することができない。本研究では、エッチ ングによる孔径拡大を利用した。エッチングを進めるとと もに孔径が拡大するため、エッチング時間によってポロシ ティの調整が可能である。

本研究では、以下に示す 4 つの処理 (工程) の組み合わせ によって微細孔形成を行った。なお、各処理はすべての条 件で実施するわけではない。

処理 (1) 洗浄および自然酸化膜の除去 - 試験片の表面の条

件を統一するため、水酸化ナトリウム水溶液 (5 wt\%) お よび硝酸 (30 wt \%) にそれぞれ 1 分間試験片を浸漬した。 本工程は全条件において実施した。

処理 (2) 電解研磨 - 平滑な試験片表面を得るために行っ た。試験片を陽極、炭素棒を陰極として、リン酸 $(80$ $w t \%)$ に浸漬した状態で電圧 $(30 \mathrm{~V})$ を 5 分間印加するこ

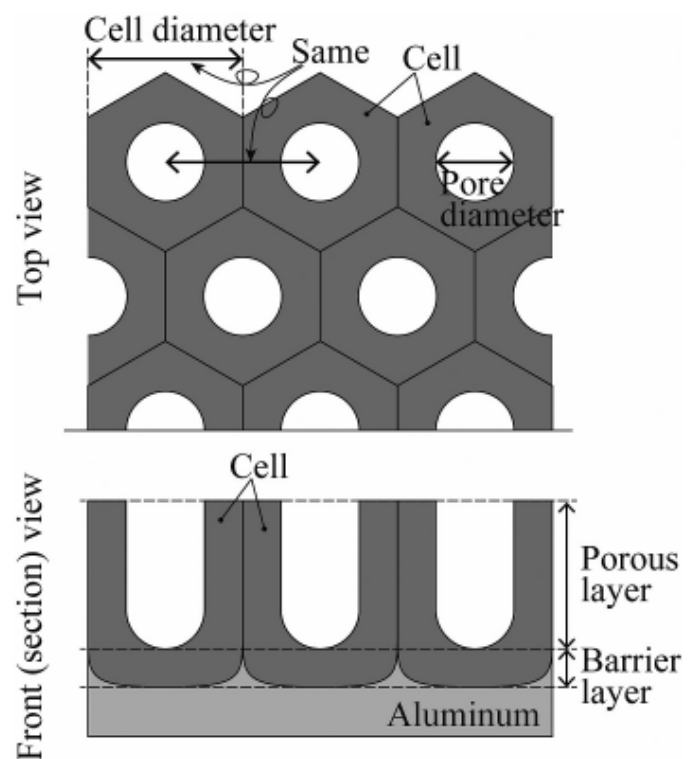

Fig. 2 Anodic porous alumina (Keller model $\left.{ }^{22)}\right)$. 
とで実施した。また、電解研磨によって、試験片表面に 酸化膜が形成される。この酸化膜を除去するため、電解 研磨後に試験片を $6 \mathrm{wt} \%$ のリン酸 $\left(\mathrm{H}_{3} \mathrm{PO}_{4}\right)$ と $2 \mathrm{wt} \%$ のク ロム酸 $\left(\mathrm{H}_{2} \mathrm{CrO}_{4}\right)$ の混合液に 30 分間浸漬した（酸化膜を 溶解させた)。

処理 (3) 陽極酸化処理 - 電解研磨と同様に、試験片を陽極、 炭素棒を陰極として電解液 (リン酸もしくはクエン酸) 中で電圧を一定時間印加した。なお、恒温槽によって処 理系を $5^{\circ} \mathrm{C} に$ 保った状態で処理を行った。

処理 (4) エッチングー陽極酸化処理によって形成された 微細孔の孔径を拡大するため、陽極酸化処理を施した 試験片をリン酸 $\left(\mathrm{H}_{3} \mathrm{PO}_{4}\right)$ もしくはリン酸とクロム酸 $\left(\mathrm{H}_{2} \mathrm{CrO}_{4}\right)$ の混合液に一定時間浸漬した。

Fig. 3 に以上の処理に用いたセットアップを示す。6枚 の試験片が同時に処理できる治具を用いてビーカー内で処 理し、治具は直流電源 (PWR400H、菊水電子工業) に接続 される。処理系の温度が制御できるようビーカーは恒温水 槽（T-10L、トーマス科学器械）の中に配置した。

本研究では大別して 3 通りの条件 (条件 I、II、III) を設 定した。条件 I では数 $10 \mathrm{~nm}$ 程度、条件 II では $200 \mathrm{~nm}$ 程度、 条件 III で $400 \mathrm{~nm}$ 程度の孔径になることを狙いとした。条 件 Iでは、処理（1）、（2）、（3）、（4）の順で実施した。条件 II では処理（1）、（3）、（4）の順で実施した。条件 I と II に おける各処理のパラメータを Table 1 に示す。数 $10 \mathrm{~nm}$ 程 度の非常に微細な構造を形成する場合、未処理面の凹凸（素 材の表面粗さ) が微細孔の発現に大きな影響を与える。そ
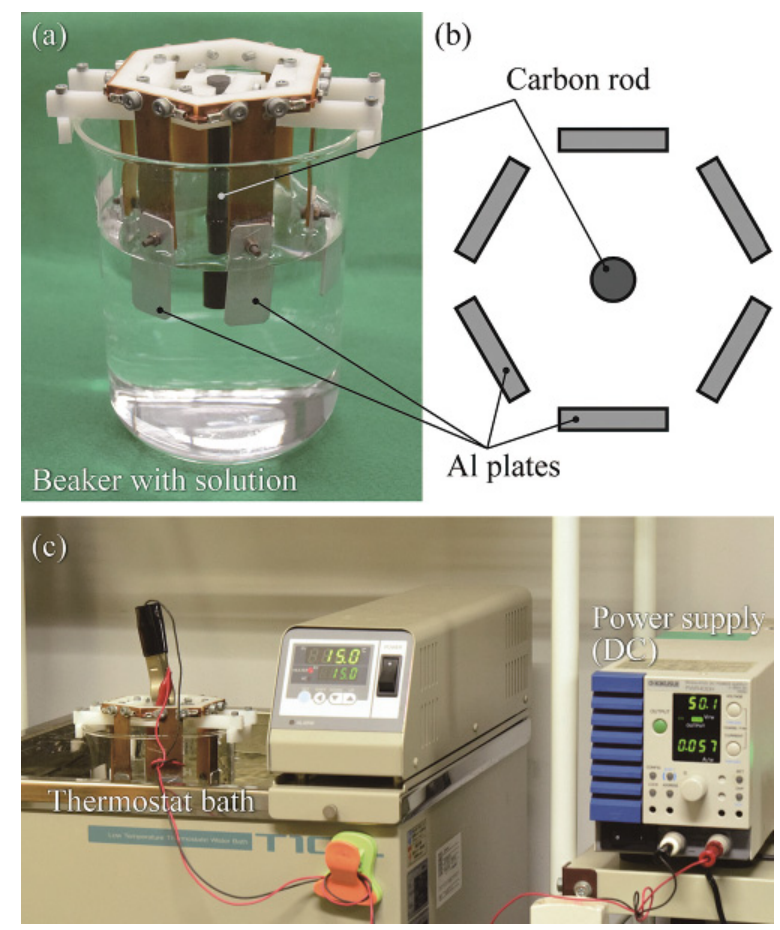

Fig. 3 Setups for anodizing and etching processes. (a, b) Six metal plates were processed simultaneously. (c) The process temperature was controlled by using a thermostat bath.
のため、条件 I においては電解研磨 (処理 (2))を行うことで、 陽極酸化処理前の面を平滑化した。一方、条件 II で狙うサ イズは、素材面の粗さの影響は無視できることが予備実験 から分かっていたため、電解研磨を行わなかった。たたし、 適した陽極酸化処理時間が不明であったため、Table 1 の 通り 4 水準の処理時間を設定した。条件 I、II 共に試験片の 材料には一般的な工業材料である A5052 アルミニウム合金 を用い、6 枚の試験片を同時に処理した（Fig.3 (a)，（b)）。

条件 III では、陽極酸化処理を 1 回行う場合 (一段階処理) と 2 回行う場合 (二段階処理)の 2 通りを検討した。二段階 処理を行うことで、形成される微細孔配列の規則性が高く なることが知られている25)。一段階処理の場合は（1）、（3）、 （4）の順で実施し、二段階処理では、（3）の後に酸化膜を 除去してから再び（3）を行い、最後に（4）を一度だけ行っ た。酸化膜除去は、試験片をリン酸 $(6 \mathrm{wt} \%)$ とクロム酸 $(2$ $\mathrm{wt} \%$ ）の混合液を恒温槽で $60^{\circ} \mathrm{C}$ に保ちながら 1 時間浸漬す ることで実施した。（3）および（4）のパラメータを Table 2 に示す。エッチング処理は複数の条件 (時間と温度)を検討 した。微細孔配列の規則性を高めるため、試験片の材料に は純アルミニウム A1050を用いた。また、6 枚の試験片を 同時に処理するには電源の出力が不十分であったため、条 件 III においては同時に処理する枚数を 3 枚とした。

Table 1 Conditions of anodizing and etching: Condition I and Condition II.

\begin{tabular}{lll}
\hline & \multicolumn{1}{c}{$\mathrm{I}$} & \multicolumn{1}{c}{$\mathrm{II}$} \\
\hline Anodizing & & \\
\hline Solution & $\mathrm{H}_{3} \mathrm{PO}_{4} 5 \mathrm{wt} \%$ & $\mathrm{H}_{3} \mathrm{PO}_{4} 5 \mathrm{wt} \%$ \\
Voltage & $50 \mathrm{~V}$ & $130 \mathrm{~V}$ \\
Processing time & $60 \mathrm{~min}$ & $30,60,90,120 \mathrm{~min}$ \\
\hline Etching & & \\
\hline Solution & $\mathrm{H}_{3} \mathrm{PO}_{4} 5 \mathrm{wt} \%$ & $\mathrm{H}_{3} \mathrm{PO}_{4} 5 \mathrm{wt} \%$ \\
Processing time & $25 \mathrm{~min}^{2}$ & $25 \mathrm{~min}$ \\
\hline
\end{tabular}

Table 2 Conditions of anodizing and etching: Condition III.

\begin{tabular}{lll}
\hline & \multicolumn{1}{c}{ One-step process } & \multicolumn{1}{c}{ Two-step process } \\
\hline Anodizing & & \\
\hline Solution & citric acid $4 \mathrm{wt} \%$ & citric acid $4 \mathrm{wt} \%$ \\
Voltage & $250 \mathrm{~V}$ & $250 \mathrm{~V}$ \\
Processing time & $120 \mathrm{~min}$ & $1 \mathrm{st}: 30 \mathrm{~min}$ \\
\hline Etching & & $2 \mathrm{nd}: 120 \mathrm{~min}$ \\
\hline Solution & $\mathrm{H}_{3} \mathrm{PO}_{4} 6 \mathrm{wt} \%$ & $\mathrm{H}_{3} \mathrm{PO}_{4} 6 \mathrm{wt} \%$ \\
Processing time & $40,60,80 \mathrm{~min}$ & $\mathrm{H}_{2} \mathrm{CrO}_{4} 2 \mathrm{wt} \%$ \\
Temperature & $40,50,60^{\circ} \mathrm{C}$ & $40,60,80 \mathrm{~min}$ \\
\hline \hline
\end{tabular}




\section{3. 評価方法}

\section{1 電子顕微鏡観察および画像処理}

表面処理を施した金属片表面を電界放出型走査型電子顕 微 鏡 (Field Emission Scanning Electron Microscope, FE-SEM. S-4800, 日立ハイテクノロジーズ)を用いて観察した。また、 FE-SEM で撮影した画像を基に、画像処理を施すことでポ ロシティの計算を行った。具体的なポロシティの計算方法 は次の通りである。まず、撮影された画像を白黒の二值化 画像に変換した。二值化のための閾值は、各画像の変換の 様子をリアルタイムで見ながら適宜調整した。そして、次 式からポロシティ $P[\%]$ を算出した。

$$
P=100 \times \frac{n_{\text {black }}}{n_{\text {all }}}
$$

ここで、 $n_{\text {black }}$ は画像中の黒色ピクセルの数 (= 孔部) で、 $n_{\text {all }}$ は全ピクセルの数である。

\section{2 成形接合を介した評価}

\subsection{1 射出成形}

各条件で表面処理を施したアルミニウム試験片を用いて 成形接合を行った。使用した樹脂材料はガラス繊維強化 型 (GF $30 \mathrm{wt} \%$ ) PBT (Polybutylene terephthalate. 1101G-X54, 東レ) である。射出成形では電動射出成形機 (ROBOSHOT

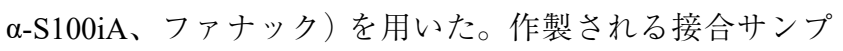
ルはISO19095に従う重ね継手構造で、Fig. 4 に示す通りで ある。金型は重ね継手が形成できるような構造になってお り、型内部の圧を計測できるよう圧センサ（6158A，キス ラー) が取り付けられている。

Table 3 に成形条件を示す。先行研究で接合への依存性 が変化した射出速度のみ複数水準設け、その他は一定值に した。これらの值はこれまでの研究 ${ }^{17)}$, 18) を基に決定した。 パラメータのうち、パック圧 (Packing pressure) は、樹脂が キャビティ内に完全充填された直後に型内で計測される圧 のピーク值を指す。これは射出成形機で直接設定できるも のではないが、射出量を試行錯誤的に調整することで、所 (a)

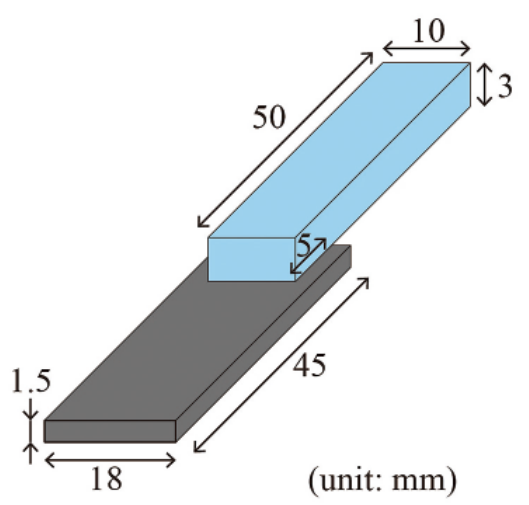

(b) Parting line

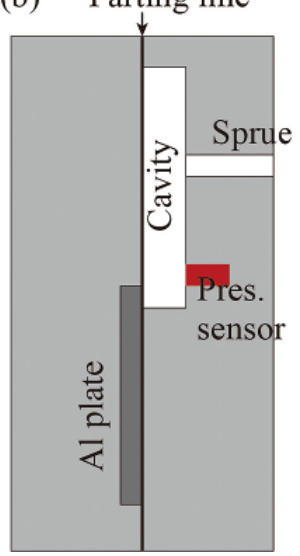

Fig. 4 Schematic illustrations of (a) single-lap joint (IMDJ sample) and (b) mold for IMDJ.
望の值になるよう設定した。

\subsection{2 接合強度評価}

作製した接合サンプルの接合強度を評価するため、引張 せん断試験を行った。接合が破断するまで、重ね継手の長 手方向に一定速度 $(1 \mathrm{~mm} / \mathrm{min})$ で引っ張り、その間の荷重 を計測した。そして、破断までの最大荷重を接合面積 $(5$ $\mathrm{mm}^{2}$ ) で除したものを引張せん断強度として記録した。各

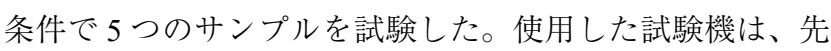
行研究で独自に開発したものである26)。

\subsection{3 樹脂の侵入量評価}

微細孔への樹脂の侵入量の計測を行った。まず、各条件 で作製した接合サンプルを塩酸 $(14 \mathrm{wt} \%)$ に 4 時間以上浸 漬することで、アルミニウム部のみを溶解し、微細孔に 侵入していた樹脂部 (突起) を露出させた。その後、露出 させた樹脂部を原子間力顕微鏡 (Atomic force microscope, AFM. L-trace II，日立ハイテクサイエンス）を用いて計測す ることで、微細孔に侵入していた樹脂の侵入量（突起の高 さ）を調べた。ただし、射出成形によって接合できず、金 型から取り出した時点で成形樹脂とアルミニウム片が分離 した条件のものもあった。これらについては、接合しなかっ たとしても微細孔への侵入は確認できる可能性があったた め、アルミニウム片から分離した樹脂をそのまま AFM で 計測した。測定範囲は、条件 I で $1 \times 1 \mu \mathrm{m}$ 、条件 II で $3 \times$ $3 \mu \mathrm{m}$ 、条件 III で $5 \times 5 \mu \mathrm{m}$ に設定した。 $x$ 軸および $y$ 軸そ れぞれで測定範囲を 256 点に分割して高さ $(z)$ を計測した。 使用したカンチレバーはSI-DF402P（日立ハイテクサイエ ンス)である。

\section{4. 実験結果と考察}

\section{1 陽極酸化処理面の観察結果}

Fig. 5 に条件 I で作製したアルミニウム片表面の SEM 像 を示す。（a）がエッチングをする前、（b）がエッチング後の サンプルである。この条件では、エッチングによって微細 孔の孔径は大きくは変わっていないが、ポロシティを求め るとエッチング前は 35\%、エッチング後は $43 \%$ となってお り、エッチングの効果を定量的に確認できた。

Fig. 6 に条件 II で作製したアルミニウム片表面の SEM 像を示す。（a）がエッチング前（陽極酸化処理時間 60 分） で（b）がエッチング後のサンプルである。（b-1）から（b-4） はそれぞれ異なる陽極酸化処理時間の結果になる。エッチ ング前は、孔径は小さいもののセル径 (微細孔間距離) は

Table 3 Molding condition

\begin{tabular}{|c|c|c|c|}
\hline Mold temperature & $140^{\circ} \mathrm{C}$ & $\begin{array}{l}\text { Cylinder } \\
\text { temperature }\end{array}$ & $165^{\circ} \mathrm{C}$ \\
\hline Packing pressure & $80 \mathrm{MPa}$ & $\begin{array}{l}\text { Cylinder } \\
\text { diameter }\end{array}$ & $22 \mathrm{~mm}$ \\
\hline Holding pressure & $40 \mathrm{MPa}$ & Cycle time & $1.5 \mathrm{~min}$ \\
\hline
\end{tabular}

Injection speed $\quad 10,100,200,300 \mathrm{~mm} / \mathrm{s}$ 


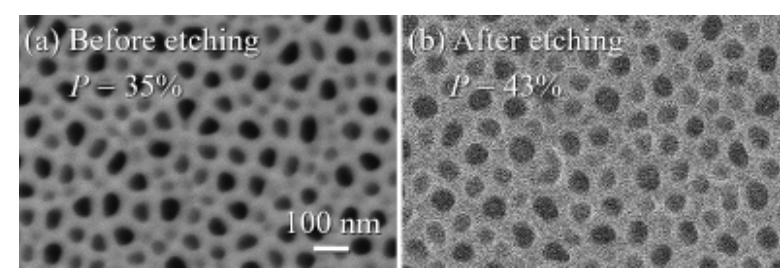

Fig. 5 SEM images of aluminum surfaces in Condition I: (a) before etching; (b) after etching.

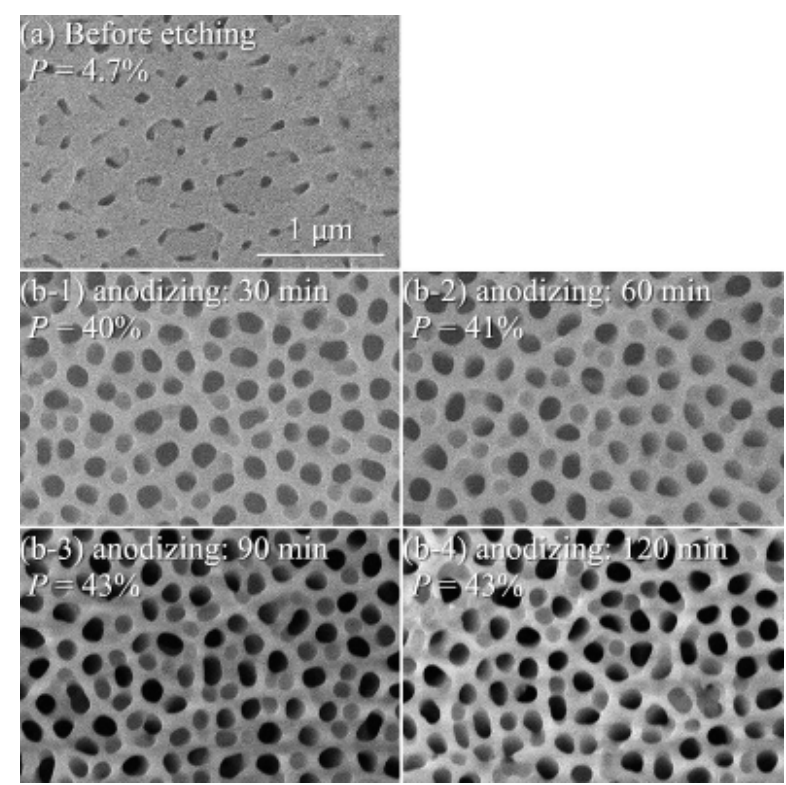

Fig. 6 SEM images of aluminum surfaces in Condition II: (a) before etching (anodizing time: $60 \mathrm{~min}$ ); (b) after etching. (b-1) to (b4) : anodizing time: $30,60,90,120 \mathrm{~min}$, respectively.

条件Iよりもはるかに大きくなっており、エッチングに よって孔径を大きくしても、微細孔間がつながらない距離 が確保できていることが分かる。陽極酸化処理時間の違い を見ると、孔径に関しては影響を受けていないことが分か る。これはポロシティ $P$ が大きく変化していない $(40$ から 43\%)ことからも確認できる。ただし、処理時間が短いも の（(b-1)、(b-2)) では、底面が見えるほど浅くなっている 微細孔の頻度が高くなっていた。処理時間が長くなるほど 酸化膜が膜厚方向に成長するため、処理時間は水平方向 (孔 径）には影響を与えないが、鉛直方向（孔深さ）には影響し ていることが確認できた。処理時間が $90 \mathrm{~min}$ 以上であれば 十分な深さの微細孔が形成されていると判断し、次節で述 ベる接合強度を評価するための成形接合サンプルの作製に

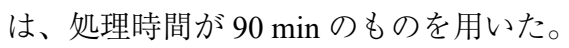

条件 III に関しては、一段階処理、二段階処理ともに全 体的に不安定で、処理できている部分とできていない部分 のバラツキが大きかった。特にエッチング温度が $60^{\circ} \mathrm{C}$ の場 合はすべての条件で非常に激しい反応を起こし、安定して 処理を行うことができなかった。比較的安定して処理でき たものの SEM 像を Fig. 7 (一段階処理) およびFig. 8 (二 段階処理)に示す。どちらの処理においても、(a)がエッチ
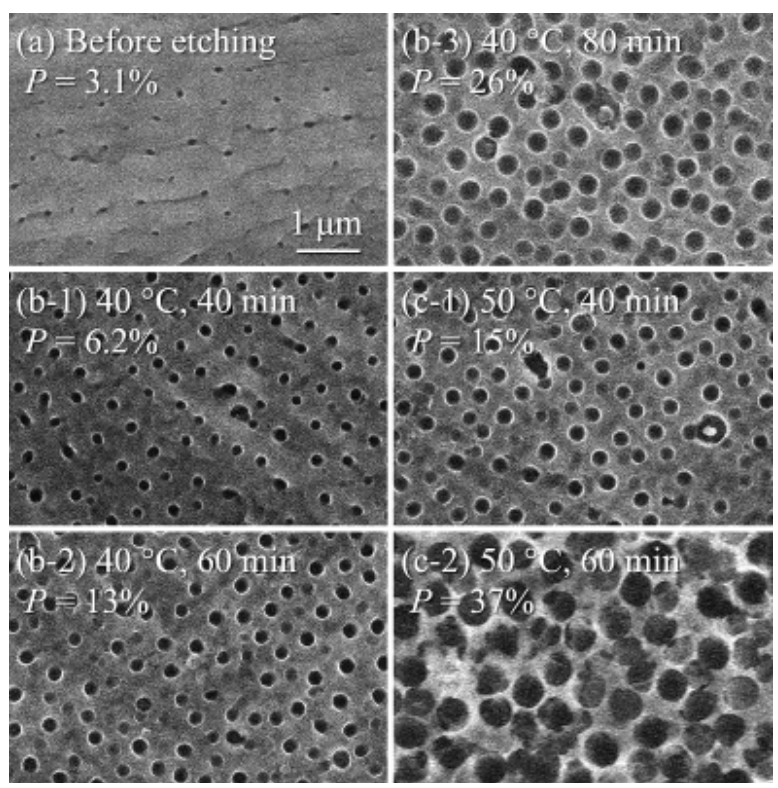

Fig. 7 SEM images of aluminum surfaces treated by 1-step anodizing process in Condition III: (a) before etching; (b, c) after etching. The etching parameters were shown in each image.

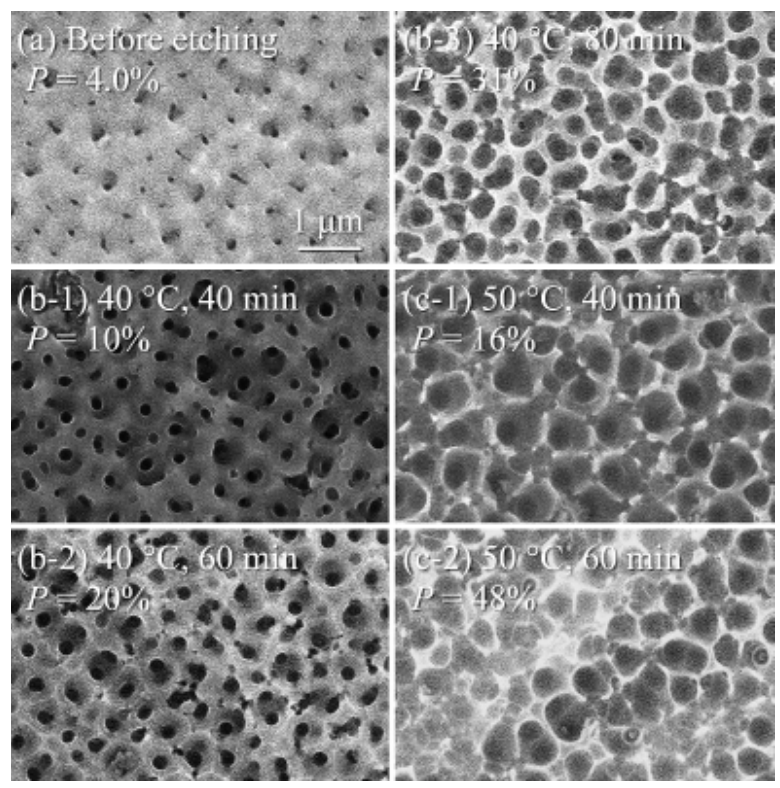

Fig. 8 SEM images of aluminum surfaces treated by 2-step anodizing process in Condition III: (a) before etching; (b, c) after etching. The etching parameters were shown in each image.

ング前で（b) および (c) がエッチング後である。（b）と（c) はそれぞれエッチング処理温度が $40^{\circ} \mathrm{C}$ の場合と $50^{\circ} \mathrm{C}$ の場 合で、-1 から-3 はそれぞれエッチング時間 40、60、80 min を示している。エッチング前の画像から、条件 I や II と比 べて大きいセル径ができていることが分かる。また二段階 処理の方が、はっきりとしたセルが確認できる。エッチン グ後に関しては、どちらの処理回数においても、50ㄷ 60 $\min$ 以上エッチングした場合、酸化膜の膜厚が十分ではな かったために微細孔が（部分的に）消失したり、隣接する微 
細孔が一体化してしまったりする様子が確認できた。最も

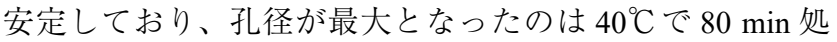
理したものであり、孔径は約 $400 \mathrm{~nm}$ になった。ポロシティ は、条件 I、II と比べると低いが、より高いポロシティを求 めるとバラツキを抑えることができなかったため、この条 件 $\left(40^{\circ} \mathrm{C} \cdot 80 \mathrm{~min}\right)$ のものを次節で述べる接合強度を評価す るための成形接合サンプルの作製に用いた。

\section{2 接合強度の試験結果}

Fig. 9 に接合強度の試験結果を示す。横軸は射出速度で 縦軸が引張せん断強度である。マーカーは平均值、エラー バーは標準偏差を示している $(N=5)$ 。条件 III においては、 射出速度が $10 \mathrm{~mm} / \mathrm{s}$ (最も遅い条件) では接合できたが、高 速な条件ではすべて接合ができなかった（金型から取り出 した時点でアルミニウム片と分離していた）。そのためこれ らの条件では接合強度を $0 \mathrm{MPa}$ としてプロットしてある。

条件 I と同等の孔径 (50 から $70 \mathrm{~nm}$ 程度) を持つ構造の 場合は従来も接合することができていた ${ }^{17)}$ が、条件 II と同 等の構造 (孔径 200 から $300 \mathrm{~nm}$ 程度) では、孔の形成はで きていたものの、接合することはできていなかった ${ }^{18)}$ 。そ れに対し、今回は接合することができた。今回接合できた のは、ポロシティを条件 I と同程度 $(40 \%$ 程度) まで高める ことができたためだと考えられる。

射出速度と接合強度の相関を見ると、すべての陽極酸化 条件において、射出速度が高くなるほど接合強度が低下し ている（負の相関がある）ことが分かる。この傾向は、従 来研究において化学処理によって形成したナノ構造を用い た場合 ${ }^{15,16)}$ や陽極酸化処理による微細孔を用いた場合 ${ }^{17)}$ と 同様である。条件 III (400 nm 程度の構造) は、これまでの ナノ構造よりは大きいものになるが、低射出速度 $(10 \mathrm{~mm} / \mathrm{s})$ で接合しており、高速な場合に接合できていない（接合強 度 $0 \mathrm{MPa})$ こから、この傾向は変わらなかったと想定で きる。構造が大きくなることで射出速度との相関性が逆転 する現象 ${ }^{16)}$ を確認するためには、さらに大きい孔を形成す る必要があることが示唆された。

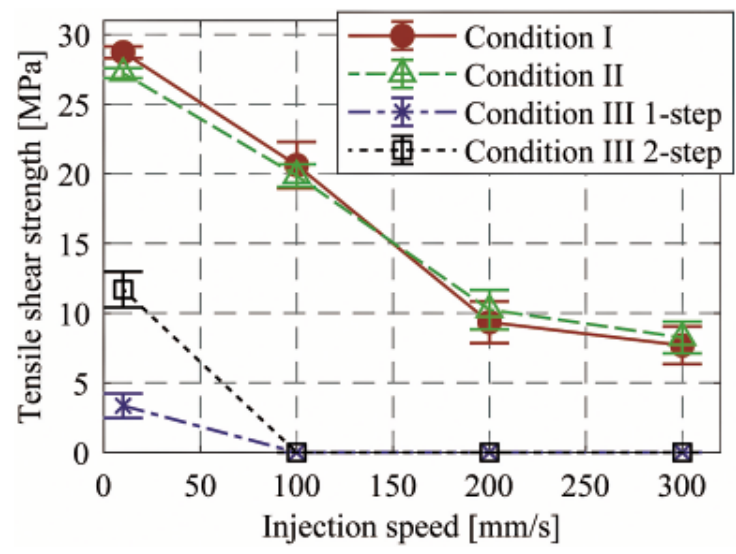

Fig. 9 Relationship between injection speed and tensile shear strength of IMDJ sample using different anodizing conditions.
条件 I と II の間には、接合強度においては全く違いが見 られなかったが、条件 III のものは全体的に低強度になった。 これは、条件 III においてポロシティを条件 I や II と同程度 まで高めることができなかったことが主な原因だ考えら れる。大構造（孔径 $400 \mathrm{~nm}$ 以上）においてポロシティを高 くする手法を確立することが今後の重要課題である。

接合強度が高いもの（20 MPa 以上）では、樹脂の凝集破 壊が主な破断モードであったが、接合強度が小さくなるに つれて部分的に界面破壊に変化していった。そして、条件 III のものでは全面で界面破壊（剥離）となった。

\section{3 樹脂侵入量の計測結果}

アルミニウム部を溶解させ、露出した突起を AFM で計 測した結果を Fig. 10 から 13 に示す。それぞれ、条件 I、 条件 II、条件 III の一段階処理、条件 III の二段階処理の結 果である。（a）は低射出速度条件 $(v=10 \mathrm{~mm} / \mathrm{s}) 、(\mathrm{~b})$ は高

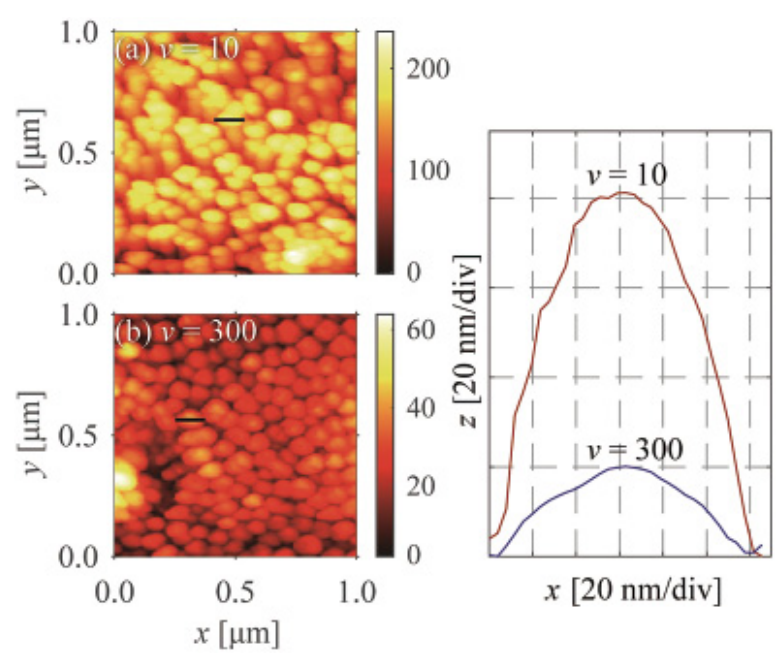

Fig. 10 AFM measurement result of plastic protrusions infiltrating into nano pores produced under Condition I.

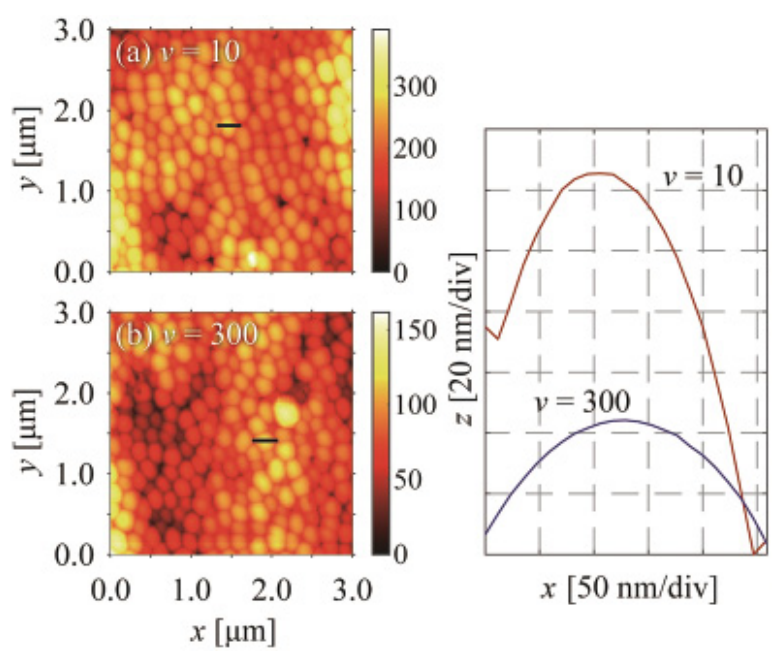

Fig. 11 AFM measurement result of plastic protrusions infiltrating into nano pores produced under Condition II. 


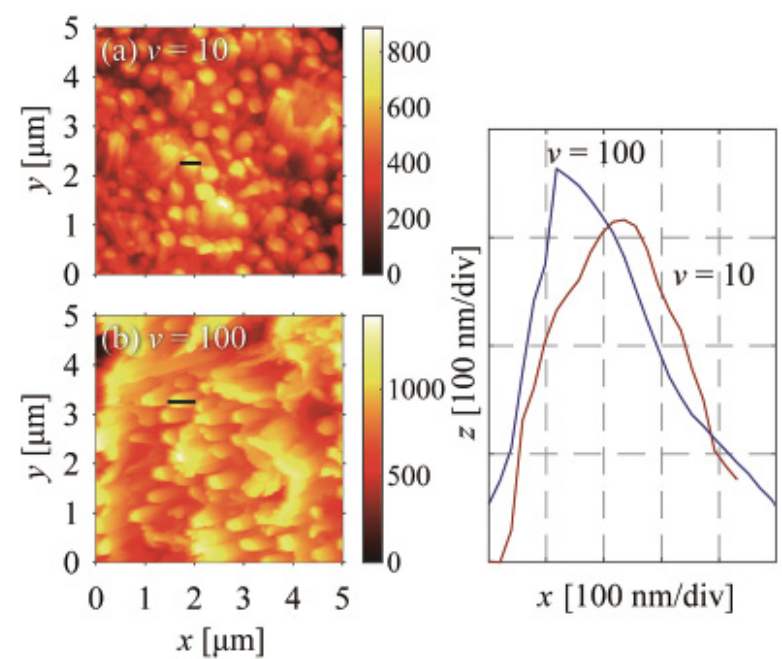

Fig. 12 AFM measurement result of plastic protrusions infiltrating into nano pores produced under Condition III 1-step.

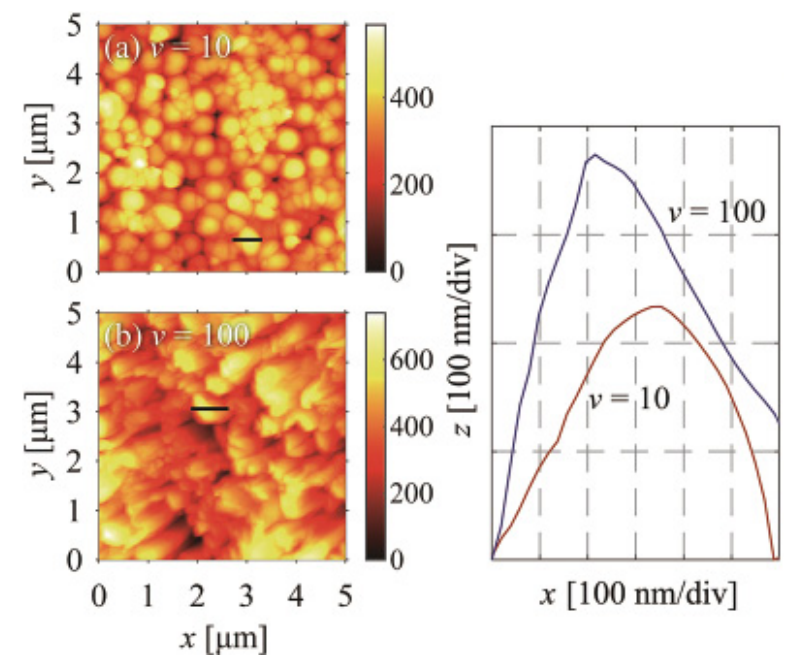

Fig. 13 AFM measurement result of plastic protrusions infiltrating into nano pores produced under Condition III 2-step.

速条件 (条件 I および II では $v=300 \mathrm{~mm} / \mathrm{s}$ 、条件 III では $v=$ $100 \mathrm{~mm} / \mathrm{s}$ )を示しており、カラーバーは高さ（単位 $\mathrm{nm}$ )を 表している。また、それぞれの AFM 画像中に描かれてい る黒い横線部の断面プロファイルを各図の右側のグラフに 示す。な拆、プロファイルを抽出する黒い線分は、代表的 な突起を通過するように選んでいるが、他の突起部分を選 んだ場合でも得られるプロファイルの特徴および傾向は以 下で述べるものと同様であった。

条件 I および II では、低射出速度の方が突起が高くなっ ていることが分かる。突起が高いほど、接合時に微細孔に より梁く侵入していることを意味しており、アンカー効果 が高くなることが予想できる。これは前節で示した射出速 度と接合強度の関係と同じ傾向であることから、妥当なも のであると考えられる。ただし、突起の根本部分の直径を 見ると、条件 I、II ともに元の微細孔の孔径よりも大きくなっ
ていることが分かる。これは、樹脂の突起が圧縮された状 態で微細孔に侵入していたが、金属を溶解させたことで解 放され、大きくなったのだと考えられる。また、AFMで使 用したカンチレバーの先端角度が拈よそ 30 度であるため、 構造の谷部分に針先が到達できず、計測された構造がオフ セットを含んでしまったことも、原因の 1 つとして考えら れる。いずれにせよ、射出速度の影響の傾向を確認する上 では十分であると考えられる。

条件 III の場合は、どちらの処理においても、射出速度 が高い方で突起が高くなっていた。ただし、高射出速度の ものは突起の形状が他のものに比べて鋭く、樹脂が微細孔 に侵入途中に冷えて固化したような形状であった。加えて、 形状が鋭いことから、圧縮されて微細孔に侵入したわけで はないことが予想できる。条件 III において高射出速度の場 合に接合強度が低かったのは、侵入深さが短かったのでは なく、侵入途中で固化し、圧縮されなかったことが原因と なる可能性がある。つまり、射出速度に依らず侵入する部 分が圧縮されるような成形条件を用意すれば、射出速度と 接合強度が正の相関を持つ可能性がある。そうなると、孔 径が 70 から $200 \mathrm{~nm}$ では負の相関であったのが $400 \mathrm{~nm}$ ら正の相関に切り替わることが確認できるようになる。サ イズのみが異なる同等形状 (相似形状) を用いて、この相関 の正負の切り替わりを見つけることが、接合発現メカニズ ムの解明に重要であると考えているため、今後の研究では、 条件 III のような大孔径でも接合できる条件を探索していき たい。

\section{5. 結 論}

表面に微細構造が形成された金属と射出成形樹脂を接合 させる成形接合において、接合が発現するメカニズムの解 明を進めるためには、微細構造をナノメートルオーダで高 精度に制御する必要がある。本研究では、陽極酸化処理を 用いることで、相似性を維持したままサイズのみを変化さ せる微細構造形成技術について検討した。陽極酸化処理打 よびエッチング処理のパラメータを精査することで、異な るサイズであってもポロシティを同等にする条件を確認で きた。また、異なるサイズの微細孔配列を有する金属片を 用いて成形接合サンプルを作製し、そのサンプルの強度お よび樹脂侵入量を評価した。強度に関しては、どのサイズ であっても射出速度と負の相関を有していたが、侵入量に 関しては、最も大きい微細孔において相関性が逆転するこ とが分かった。このことから、微細孔のサイズによって、 溶融樹脂の侵入挙動が変化していることが想定でき、将来 的にこの挙動を詳しく調査することが接合発現メカニズム の解明につながると考えられる。今後の研究では、陽極酸 化処理打よびエッチング処理に打いて、より多様な条件を 調查することで、孔径やポロシティに加えて配列の規則性 などもより高精度に制御することを検討していく。また、 より広範囲の射出成形条件を併せて調査することで、樹脂 
の微細孔への侵入挙動・接合が発現する様子を明らかにし ていきたい。

\section{謝 辞}

本研究は JSPS 科研費（\#20H02041）および一般財団法人 生産技術研究奨励会の助成を受けて行われた。

\section{参考文献}

1) S. Katayama and Y Kawahito: "Laser direct joining of metal and plastic", Scr. Mater., 59-12 (2008) 1247-1250.

2) A. Fortunato, G. Cuccolini, A. Ascari, L. Orazi, G. Campana, and G. Tani: "Hybrid metal-plastic joining by means of laser", Int. J. Mater. Form., 3-1 (2010) 1131-1134.

3) J. Holtkamp, A. Roesner, and A. Gillner: "Advances in hybrid laser joining”, Int. J. Adv. Manuf. Technol., 47-9-12 (2010) 923-930.

4) F. Balle, G. Wagner, and D. Eifler: "Ultrasonic Metal Welding of Aluminium Sheets to Carbon Fibre Reinforced Thermoplastic Composites", Adv. Eng. Mater., 11-1-2 (2009) 35-39.

5) E. E. Feistauer, R. P. M. Guimarães, T. Ebel, J. F. dos Santos, and S. T. Amancio-Filho: "Ultrasonic joining: A novel direct-assembly technique for metal-composite hybrid structures", Materials Letters, 170 (2016) $1-4$

6) S. T. Amancio-Filho, C. Bueno, J. F. dos Santos, N. Huber, and E. Hage Jr: "On the feasibility of friction spot joining in magnesium/ fiber-reinforced polymer composite hybrid structures", Materials Science and Engineering: A, 528-10-11 (2011) 3841-3848.

7）永塚公涁, 斧田俊樹, 岡田俊哉, 中田一博: “摩擦重ね接合による $\mathrm{Mg}$ 添加量の異なる種々のアルミニウム合金/樹脂の直接異材 接合”, 溶接学会論文集, 32-4 (2014) 235-241.

8）永塚公涁他: “抵抗スポット溶接を応用した金属と炭素繊維強 化樹脂の直接異材接合”, 溶接学会論文集, 34-4 (2016) 267-273.

9) M. Grujicic et al.: "An overview of the polymer-to-metal directadhesion hybrid technologies for load-bearing automotive components", J. of Mater. Process. Technol., 197-1-3 (2008) 363373.

10) K. Ramani and B. Moriarty: "Thermoplastic bonding to metals via injection molding for macro-composite manufacture", Polym. Eng. \& Sci., 38-5 (1998) 870-877.

11) G. Lucchetta, F. Marinello, and P. F. Bariani: "Aluminum sheet surface roughness correlation with adhesion in polymer metal hybrid overmolding”, CIRP Ann., 60-1 (2011) 559-562.

12) Y. Kajihara, Y. Tamura, F. Kimura, G. Suzuki, N. Nakura, and E. Yamaguchi: "Joining strength dependence on molding conditions and surface textures in blast-assisted metal-polymer direct joining", CIRP Ann., 67-1 (2018) 591-594.
13）安藤直樹: “NMT: アルミ合金に対する熱可塑性エンプラの射出 接合技術”, 成形加工, 16-9 (2004) 588-591.

14） P. A. Fabrin, M. E. Hoikkanen, and J. E. Vuorinen: "Adhesion of thermoplastic elastomer on surface treated aluminum by injection molding”, Polym. Eng. \& Sci., 47-8 (2007) 1187-1191.

15) F. Kimura, S. Kadoya, and Y. Kajihara: "Effects of molding conditions on injection molded direct joining using a metal with nano-structured surface”, Precis. Eng., 45 (2016) 203-208.

16) F. Kimura, S. Kadoya, and Y. Kajihara: "Effects of molding conditions on injection molded direct joining under various surface fine-structuring”, Int. J. Adv. Manuf. Technol., 101-9 (2019) 27032712.

17) S. Kadoya, F. Kimura, and Y. Kajihara: "PBT-anodized aluminum alloy direct joining: Characteristic injection speed dependence of injected polymer replicated into nanostructures", Polymer Testing, 75 (2019) 127-132.

18) S. Kadoya, F. Kimura, T. Yanagishita, and Y. Kajihara: "Structure size effect on polymer infiltration in injection molded direct joining", Precis. Eng., 67 (2021) 100-109.

19) J. Byskov-Nielsen, J. V. Boll, A. H. Holm, R. Højsholt, and P. Balling: "Ultra-high-strength micro-mechanical interlocking by injection molding into laser-structured surfaces", Int. J. of Adhes. and Adhes., 30-6 (2010) 485-488, 2010.

20）瀬戸雅宏, 朝見芳弘, 板倉雅彦: “樹脂-金属接合射出成形品の接 合強さに与える成形条件の影響”, 成形加工, 27-2 (2015) 68-74.

21) B. Huang, L. Sun, L. Li, L. Zhang, Y. Lin, and J. Che: "Experimental investigation of the strength of polymer-steel direct adhesion (PSDA) joints with micro-structures ablated by laser," J. of Mater. Process. Technol., 249 (2017) 407-414.

22) F. Keller, M. S. Hunter, and D. L. Robinson: "Structural Features of Oxide Coatings on Aluminum”, J. Electrochem. Soc., 100-9 (1953) 411-419.

23) H. Masuda and K. Fukuda: "Ordered Metal Nanohole Arrays Made by a Two-Step Replication of Honeycomb Structures of Anodic Alumina", Science, 268-5216 (1995) 1466-1468.

24）高橋英明: “アノード酸化ポーラスアルミナ研究の過去・現在 · 未来”, 表面技術 62-7 (2011) 324-324.

25）益田秀樹, 柳下崇, 近藤敏彰: “アルミナナノホールアレーの新 展開”, Electrochemistry, 83-11（2015）1006-1011.

26) S. Kadoya, F. Kimura, and Y. Kajihara: "Tester for tensile shear evaluation of metal-polymer single lap joints", Precis. Eng., 54 (2018) 321-326.

代表者メールアドレス

木村文信 fuminobu@iis.u-tokyo.ac.jp 